\title{
PENGUKURAN TINGKAT EFISIENSI BANK SYARIAH DAN BANK KONVENSIONAL DI INDONESIA DENGAN FORMULA DAVID COLE'S ROE FOR BANK
}

\author{
Bachruddin \\ Fakultas Ekonomi Universitas Islam Indonesia
}

\begin{abstract}
This research was aimed to analyze the difference in the rate of efficiency between the group of Syariah Bank with the group of conventional Banks in Indonesia during 2003 and 2004. To analyze the rate of efficiency indicated by the Rate of Return (ROE), the research uses three factors namely Profit Margin (PM), Asset Utilization $(A U)$ and Equity Multiplier (EM). The research was based on secondary data consisted of financial reports collected from the said two group of banks, comprising 4 Syariah Bank and 4 Conventional Banks, for the period of 2003 and 2004.

The tools of analysis used in the research consisted of two methods. The first was variance test analysis for the average of ROE between the two groups of banks. The second was regression analysis applied for each group of banks. In this model, the factors i.e. PM, AU and EM were estimated to influence the ROE.

The result of the research showed that the ROE of Syariah Bank was significantly difference with the ROE of Conventional Banks. In this result the standard deviation of ROE of Syariah Banks was smaller than conventional banks. Further, the result indicated that PM, AU and EM of Syariah Bank were significantly influenced to ROE. Meanwhile, the three factors were not significantly influenced to ROE of Conventional Banks.

In order to get the better result in the next research of this topic, the number of samples should be greater and it is suggested to apply the other method of analysis like discriminate analysis. Further, the period of empirical study should be longer at least five years.
\end{abstract}

Keywords: rate of efficiency, profit margin, asset utilization, equity multiplier, bank syariah

\section{LATAR BELAKANG MASALAH}

Keberadaan sektor perbankan sebagai sub-sistem dalam perekonomian suatu negara memiliki peranan yang cukup penting. Bahkan dalam kehidupan masyarakat modern sehari-hari, sebagian besar hampir melibatkan jasa-jasa dari sektor perbankan (Rose, 1995: 5). Hal demikian kiranya dapat dipahami karena sektor perbankan mengemban suatu fungsi utama sebagai perantara keuangan antara unit-unit ekonomi yang surplus dana dengan unit-unit ekonomi yang kekurangan dana (Sinungan, 1987: 111). Melalui bank-bank dapat dihimpun dana-dana dari masyarakat dalam berbagai bentuk simpanan. Selanjutnya dari dana yang terkumpul tersebut, oleh bank-bank dapat disalurkan kembali dalam bentuk pemberian kredit kepada sektor bisnis atau pihak-pihak yang membutuhkan lainnya. Semakin berkembang kehidupan masyarakat dan transaksi-transaksi perekonomian suatu negara, akan membutuhkan pula peningkatan peran sektor perbankan melalui pengembangan produk-produk jasanya (Hempel, 1994: 3).

Sektor perbankan di Indonesia telah memiliki peran yang cukup lama yaitu sejak zaman penjajahan Belanda. Hanya saja dalam perjalanannya, baru mendapat- 
kan momentum yang cukup berarti sejak 1 Juni 1983, saat mana pemerintah mengeluarkan serangkaian kebijakan-kebijakan dalam rangka deregulasi perbankan (Hadiwigeno, 1982: 62). Mulai periode ini, industri perbankan Indonesia dapat dikatakan memasuki suatu era liberalisasi perbankan. Artinya bank-bank dapat secara relatif bebas menentukan strategi-strategi dan kebijaksanaan-kebijaksanaan yang menyangkut pagu kredit, bunga kredit, bunga simpanan dan upaya-upaya pengembangan usaha serta produk-produk yang ditawarkan. Melalui paket-paket deregulasi ini, sektor perbankan Indonesia mengalami perkembangan yang pesat, bila dilihat pada data stratistik dari periode 1983-1990 (Infobank N. 130, 1990: 20). Kalau pada tahun 1983 jumlah bank yang ada 118 buah maka pada tahun 1990 meningkat menjadi 155 buah. Hal ini membawa dampak pada peningkatan volume dana masyarakat yang dapat dihimpun, yaitu dari sebesar Rp 23,86 triliyun pada tahun 1983 menjadi Rp 108,38 triliyun pada tahun 1990. Begitu pula volume kredit yang diberikan telah naik cukup tajam, yaitu dari Rp 26,92 triliyun pada tahun 1983 menjadi Rp 302,10 triliyun pada tahun 1990.

Dalam perkembangan selanjutnya, industri perbankan Indonesia masih terus mengalami peningkatan sampai dengan tahun 1996. Pada tahun ini, jumlah bank tercatat menjadi 239 buah, suatu pertumbuhan yang hampir 3 kali lipat bila dibanding pada keadaan tahun 1990 sebanyak 115 buah bank. Dari jumlah tersebut, bagian terbesar adalah bank-bank swasta nasional yaitu 164 buah. Selebihnya adalah bank-bank pemerintah 7 buah, bank-bank pembangunan daerah 27 buah dan bank-bank asing 41 buah (Statistik Indonesia, 1998: 42). Pertumbuhan sektor perbankan yang semakin meningkat ini tidak lain karena ditopang oleh perkembangan sektor riil yang terus menggeliat terutama pada segmen perusahaan-perusahaan besar. Disamping itu, daya beli masyarakat juga semakin kuat khususnya dari lapisan menengah dan atas (Bank \& Manajemen No. 45, 1998).

Pada perjalanan berikutnya, yaitu tepatnya pada media tahun 1997, perekonomian Indonesia mengalami apa yang disebut dengan krisis moneter dan keuangan. Hal ini membawa akibat yang buruk bagi sektor perbankan, dimana terdapat 16 bank swasta nasional yang dilikuidasi Nasib yang kurang baik bagi jajaran perbankan nasional masih berlanjut pada tahun 1998 dimana 10 bank swasta di BTO kan, menyusul sebelumnya 4 buah bank swasta lainnya di BTO kan. Sebagai akibatnya jumlah bank per akhir 1997 menurun menjadi 222 buah dan per akhir tahun 1998 menurun lagi menjadi 208 buah (Statistik Indonesia, 1998: 48).

Dalam mencermati penomena krisis moneter seperti dipaparkan tersebut di atas ada satu hal penting yang tidak dapat diabaikan dan perlu diketengahkan yaitu mengenai eksistensi bank Syariah/Bank Islam. Ternyata bahwa bank Syariah ini tidak ikut terkena guncangan oleh badai krisis moneter, sementara bank-bank umum lainnya mejadi porak-poranda. Hal ini patut menjadi bahan kajian yang menarik secara akademik melalui pengukuran tingkat efisiensi operasional bank syariah, dibandingkan dengan bank konvensional. 
Jajaran bank syariah mengawali keberadaannya dengan berdirinya Bank Muamalat Indonesia (BMI) sebagai suatu bank umum. Dalam perkembangannya selanjutnya telah berdiri pula Bank-bank Perkreditan Rakyat Syariah (BPRS) yang sampai saat ini berjumlah 52 buah. Begitu pula Bank Muamalat Indonesia telah membuka beberapa kantor cabangnya antara lain di Bandung dan Semarang. Dari data yang dapat dikumpulkan tercatat bahwa total aktiva yang dimiliki Bank Muamalat Indonesia per akhir Oktober tahun 2000 adalah sebesar Rp 782,28 milyar, yang berarti terdapat peningkatan $28,97 \%$ dari periode sebelumnya. Laba bersih yang dicapai per Oktober 2000 sebesar Rp 11,69 milyar dengan kenaikan 148,10\% dibanding periode 1999. Sementara laba tahun berjalan 1999 sebesar Rp 3,02 milyar dan tahun berjalan 2000 sebesar Rp 17,31 milyar, yang menunjukkan terdapat peningkatan 472,74\%. Sedangkan CAR per Oktober 2000 adalah sebesar 13,11\%.

Berdasarkan angka-angka keuangan tersebut diatas dapat dicatat bahwa volume usaha dari Bank Muamalat Indonesia masih belum berarti bila dibanding dengan potensi seluruh sektor perbankan secara nasional. Namun demikian, secara nyata telah memperlihatkan suatu kinerja yang menggembirakan dan cukup efisien. Sementara bank-bank konvensional lainnya mengalami keterpurukan sebagai akibat dari krisis moneter, tetapi bank syariah ini justru mempu membubuhkan laba bahkan mengalami peningkatan yang sangat baik disertai dengan tingkat CAR yang tinggi.

Keberadaan bank syariah di Indonesia dari waktu ke waktu telah mengalami perkembangan yang cukup baik. Hal ini ditandai antara lain dengan munculnya beberapa bank konvensional yang membuka sub sektor usaha bank syariah, seperti Bank BNI Syariah, Bank Danamon, Bank IFI dan Bank Syariah Mandiri. Melalui kantor-kantor cabang yang dimiliki oleh bank-bank konvensional ini, maka operasionalisasi bank syariah semakin menjadi luas yaitu dapat menjangkau keberbagai daerah. Selain bank syariah dalam bentuk bank umum tersebut diatas, dapat dicatat pula adanya peningkatan jumlah Bank Perkreditan Rakyat Syariah (BPRS) yang pada tahun 2003 telah mencapai 85 BPRS, dimana pada tahun sebelumnya yaitu tahun 2002 berjumlah 82 BPRS.

Dari paparan hal-hal tersebut diatas, peneliti tertarik untuk mengangkat judul penelitian yaitu Pengukuran Tingkat Efisiensi Bank Syariah dan Bank Konvensional di Indonesia Periode Tahun 2003 dan Tahun 2004. Melalui penelitian ini diharapkan memberikan kontribusi baik di bidang teori, bidang metodologi dan bidang kebijakan manajemen (yang akan diutarakan pada butir E Manfaat Penelitian). Sedangkan pemilihan periode penelitian tahun 2003 dan tahun 2004 adalah atas pertimbangan suatu periode yang relatif kondusif untuk ditelaah. Setelah melewati masa krisis moneter yang diawali pada pertengahan tahun 1997. Dari tahun 1997 sampai tahun 2002, kondisi perbankan Indonesia masih mengalami fase-fase pemulihan. Adapun tujuan dari penelitian ini adalah untuk mengetahui perbedaan tingkat efisiensi dari bank syariah dan bank konvensional di Indonesia serta tingkat pengaruh dari Profit Margin, Asset Utilization dan Equity Multiplier. 


\section{LANDASAN TEORI DAN HIPOTESIS}

\section{Fungsi, Tujuan dan Bidang-bidang Manajemen Bank Lembaga keuangan Bank dan fungsi pokoknya}

Menurut Undang-undang tentang Perbankan Nomor 10 Tahun 1998 dinyatakan bahwa bank umum dibagi menjadi 2 jenis yaitu bank komersial/onvensional dan bank bagi hasil/syariah. Adapun bidang-bidang usaha yang dapat dijalankan oleh bank umum meliputi usaha perkreditan, perdangan sekuritas, perdagangan valuta asing, anjak piutang, modal ventura dan sewa guna.

Fungsi pokok bank secara umum adalah menjalankan perantara keuangan dalam masyarakat. Dalam hal ini bank, berpartisipasi dalam pasar keuangan dengan dua peranan penting, yaitu sebagai pembeli dana-dana dan sebagai penjual dana (Goldfield and Chandler, 1988: 134).

\section{Tujuan lembaga keuangan bank}

Tujuan dari lembaga keuangan bank dapat terfokus pada tiga sasaran yaitu maksimalisasi imbalan bagi pemegang saham, pertumbuhan pangsa pasar dan keunggulan layanan bagi pelanggan. Setiap lembaga keuangan bank dapat menetapkan sasaran utamanya yang bisa berbeda satu sama lainnya. Namun demikian dapat dipastikan bahwa sasaran maksimalisasi imbalan bagi pemegang saham menjadi tujuan umum, sebagaimana juga tujuan umum dari lembaga bisnis (Rose and Kolari, 181).

Untuk mengukur kinerja bank dalam mencapai tujuan maksimalisasi imbalan bagi pemegang saham dapat dipakai 2 indikator yaitu harga saham dan laba bagi pemegang saham. Bagi perusahaan atau bank yang berbentuk perseroan yang saham-sahamnya diperdagangkan secara luas dan aktif maka indikator harga saham merupakan tolok ukur efisiensi dari pencapaian tujuan perusahaan. Artinya semakin tinggi harga saham akan meningkatkan imbalan bagi pemegang saham (Rose, 1995: 182). Namun demikian, harga saham suatu perusahaan dipasar modal dapat dipengaruhi oleh beberapa faktor, meliputi faktor fundamental intern perusahaan, faktor fundamental ekonomi, faktor-faktor makro lainnya dan faktor sentimen pasar.

Bagi suatu perusahaan atau bank yang saham-sahamnya tidak diperdagangkan secara luas, harga saham tidak dapat dijadikan tolok ukur untuk menilai kinerja bank dalam mencapai tujuan pokoknya. Untuk kondisi bank seperti ini, maka dapat dipakai tolok ukur yang lebih umum yaitu rasio-rasio keuangan sebagai proksi untuk mengukur tingkat efisiensi perusahaan (Rose, 1995: 183). Adapun alat ukur utama yang dapat dipakai adalah Return On Investment (ROI) dan Return On Equity (ROE). Kalau ROI mengukur tingkat efisiensi dari investasi yang dilakukan perusahaan, sementara ROE merupakan indikator tingkat efisiensi bagi pemegang saham. Dikaitkan dengan pencapaian tujuan perusahaan untuk memakmurkan pemegang saham maka ROE merupakan tolok ukur yang lebih tepat (Rose, Cole, 1995: 185). 


\section{Bidang-bidang Manajemen Lembaga Keuangan Bank}

Dalam upaya untuk mencapai tujuan perusahaan, lembaga keuangan bank perlu melaksanakan pengelolaan operasinya melalui bidang-bidang manajemen yang meliputi manajemen aktiva, manajemen pasiva (hutang dan modal), manajemen pemasaran dan manajemen biaya (Rose and Kolari, 1995: 18).

a. Manajemen Pemasaran Bank

Bidang manajemen pemasaran bank menyangkut kebijaksanaan penentuan tingkat bunga (Pricing Policy) baik untuk dana-dana yang diperoleh dan untuk kredit atau investasilain yang dijalankan. Dalam penetapan tingkat bunga ini bank lazimnya mengharapkan berupa selisih bunga (spread) yang positif. Selain itu, bank juga menetapkan kebijaksanaan dalam penentuan volume dana-dana yang dihimpun dan volume kredit yang diberikan (Volume Policy) yang biasanya diukur dengan Banking Ratio (Loan to Deposit Ratio). Hasil dari perpaduan Pricing Policy dan Volume Policy dalam manajemen pemasaran ini akan tercermin pada Profit Margin yang dicapai. Perlu dicatat bahwa profit margin ini merupakan komponen penting (value driver) yang membentuk Return On Equity menurut Model Analisis David Cole (Rose and Kolari, 1995: 1985).

b. Manajemen Aktiva Bank

Untuk melaksanakan investasi-investasinya bank perlu menerapkan manajemen aktiva (Aset manajemen) yang baik. Agar supaya pengelolaan investasi pada berbagai usaha bank dapat dikendalikan, perlu memperhatikan kebijaksanaan portofolio baik secara keseluruhan maupun secara khusus untuk kreditnya (Loan Portofolio). Investasi dana bank ke dalam berbagai jenis aktiva dapat diklasifikasikan menjadi 2 golongan yaitu pada aktiva productif (Productive/Earning Assets) dan pada aktiva tidak produktif (Non Productive/Non Earning Assets).

Hasil dari manajemen aktiva bank ini dapat diukur dengan Net Interest Margin dan Return On Assets (Rose \& Peter S, 1982: 50-55). Selain itu tingkat efektivitas dari manajemen aktiva dapat pula diukur dengan Asset Utilization Ratio (Cole, Rose, 1995: 1985). Sesuai dengan Model David Cole, Asset Utilization ini merupakan komponen pembentuk return on Equity.

c. Manajemen Pasiva Bank

Manajemen pasiva bank menyangkut pengelolaan sumber-sumber dana, yang terdiri dari sumber dana hutang dan sumber dana modal sendiri. Sumber dana hutang meliputi komponen-komponen kewajiban segera, dana masyarakat dan hutang kepada bank lain. Tugas pokok manajemen pasiva adalah menetapkan komposisi sumber-sumber dana (Funds Mix) berdasarkan proporsi yang terbaik. (Rose \& Kolari, 1995: 357).

Untuk mengukur kinerja dari manajemen pasiva bank dapat dipakai beberapa rasio keuangan yaitu Debt Ratio atau Equity Multiplier. Menurut Model David Cole, yang cocok dipakai adalah Equity Multiplier sebagai komponen pembentuk Return On Equity. 


\section{Spesifikasi Model Return On Equity (ROE) for Bank's}

Model ROE for Banks, sebagaimana diketengahkan oleh David Cole dalam

The Banks's Magazine, Spring, (1973) adalah sebagai berikut:

Return On Equity = Fungsi dari (Profit Margin, Asset Utilization dan Equity Multiplier).

Sebagaimana telah dijelaskan sebelumnya bahwa model ROE ini merupakan pencerminan dari pengukuran pencapai tujuan bank yang dibentuk oleh komponen-komponen kinerja bidang-bidang manajemen bank, yaitu:

- Return On Equity sebagai tolok ukur pencapaian tujuan bank yaitu tingkat efisiensi bagi pemilik bank.

- Profit margin merupakan proksi dari kinerja manajemen pemasaran yang menentukan ROE.

- Asset Utilization merupakan proksi dari kinerja manajemen aktiva yang menentukan ROE.

- Equity Multiplier merupakan proksi dari kinerja manajemen pasiva (permodalan) yang menentukan ROE.

\section{Kerangka Konseptual Penelitian}

Dari spesifikasi Model Return On Equity (ROE) for Banks tersebut pada butir 2 di atas, dapatlah dijabarkan secara lebih jelas dalam Kerangka Konseptual seperti terlihat pada gambar 1.

Gambar 1. Kerangka Konseptual Penelitian

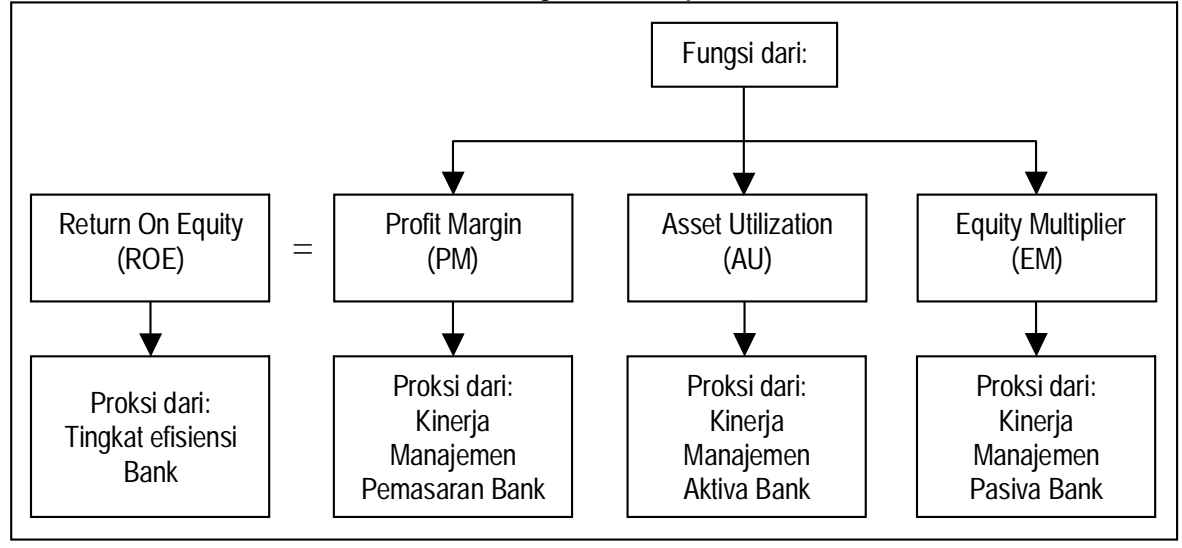

Dengan mencermati skema pada gambar 1 di atas dapat diidentifikasi tentang variabel-variabel penelitian yang akan dilibatkan dalam analisis, yaitu sebagai variabel terpengaruh (dependent variable) adalah Return On Equity (ROE) sementara itu variabel-variabel pengaruh (independent variables) meliputi: Profit Margin (PM); Asset Utilization (AU) dan Equity Multiplier (EM). 


\section{Hipotesis Penelitian}

Sesuai dengan tujuan penelitian dan kerangka konseptual di atas maka dapat dirumuskan hipotesis-hipotesis penelitian, sebagai berikut:

a. Hipotesis Pertama ( $\mathrm{H} 1$ )

Bahwa terdapat perbedaan yang berarti antara ROE yang dicapai oleh Bank Syariah dengan ROE yang dicapai oleh bank konvensional.

b. Hipotesis Kedua $(\mathrm{H} 2)$

Bahwa terdapat pengaruh yang berarti dari $P M, A U$ dan EM terhadap ROE pada Bank Syariah dan bank konvensional.

\section{METODE PENELITIAN}

\section{Populasi dan Sampel}

Semula penelitian ini direncanakan sebagai penelitian populasi yang meliputi data dari seluruh bank-bank syariah dan bank konvensional di Indonesia. Tujuannya agar diperoleh gambaran kondisi umum dari seluruh komponen bank syariah dan bank konvensional di Indonesia. Namun demikian, karena ada hambatan berupa keterbatasan dari data yang menyangkut bank-bank syariah, maka dalam pelaksanaannya penelitian ini menjadi penelitian sampel dengan mempertimbangkan ketersediaan data penelitian dari bank syariah yang dapat diperoleh.

Adapun data penelitian yang secara maksimal dapat dikumpulkan dari bank-bank syariah adalah meliputi:

口 Bank BNI Syariah;

口 Bank IFI Syariah;

- Bank Mandiri Syariah, dan

a Bank Muamalat Indonesia.

Sementara itu data penelitian yang dikumpulkan dari bank-bank konvensional adalah menyesuaikan dengan sebagian besar bank-bank syariah tersebut diatas, yang meliputi:

口 Bank BNI;

口 Bank IFI;

B Bank Mandiri Syariah, dan

口 Bank BRI Syariah

\section{Model Penelitian}

Sebagaimana telah dipaparkan pada gambar 1 kerangka konseptual diatas, maka model penelitian yang dipakai adalah sebagai berikut:

Return On Equity (ROE) = Fungsi (Profit Margin (PM); Asset Ulitizatio (AU); dan Equity Multiplier (EM)). 


\section{HASIL PENELITIAN DAN PEMBAHASAN}

\section{Hasil Penelitian}

Hasil penelitian yang dapat dilaporkan disini adaah berupa terkumpulnya data penelitian dalam bentuk laporan keuangan dari bank-bank syariah dan bankbank konvensional di Indonesia. Laporan keuangan dimaksud adalah meliputi: Neraca, Perhitungan Laba-Rugi, serta Ikhtisar Rasio Keuangan dari bank yang bersangkutan. Periode laporan keuangan yang diperlukan dalam penelitian ini adalah periode triwulanan, selama tahun 2003 dan 2004.

Jumlah laporan keuangan triwulanan yang terkumpul adalah sebanyak 32 buah dari bank-bank syariah, yang meliputi: Bank BNI Syariah; Bank IFI Syariah; Bank Mandiri Syariah dan Bank Muamalat Indonesia. Sementara itu jumlah laporan keuangan triwulan dari bank-bank konvensional sebanyak 32 buah, yaitu dari: Bank BNI; Bank IFI; Bank Mandiri dan Bank BRI.

\section{Penghitungan Variabel-variabel Penelitian}

Dari laporan-laporan keuangan untuk masing-masing bank tersebut diatas, kemudian dilakukan proses penghitungan data sebagaimana lazimnya untuk memperoleh besaran-besaran atau rasio-rasio untuk setiap variabel penelitian. Adapun variabel-variabel penelitian yang dihitung adalah Return On Equity (ROE); Profit Margin (PM); Asset Utilization (AU) dan Equity Multiplier (EM) untuk setiap triwulan dalam tahun 2003 dan 2004.

\section{Pembuktian Hipotesis Pertama}

Untuk pembuktian hipotesis pertama, dipakai alat analisi Uji Beda Dua Rata-rata dari ROE atau Uji t statistik dari ROE.

Perumusan hipotesis pertama adalah sebagai berikut:

Ho : ROE (BS) = ROE (BK)

$\mathrm{H} 1: \mathrm{ROE}(\mathrm{BS}) \neq \mathrm{ROE}(\mathrm{BK})$

Hasil analisis dengan memakai tingkat kepercayaan 95\% $(\mathrm{a}=0,05)$ dan derajat kebebasan $(\mathrm{df})=31$, diperoleh $t$-hitung $=5,580$ dengan tingkat signifikansi $=$ 0,000 .

Berdasarkan hasil ini maka dapat disimpulkan bahwa hipotesis pertama dapat terbukti, yaitu terdapat perbedaan yang berarti dari ROE pada Bank Syariah dengan ROE pada Bank konvensional.

\section{Pembahasan}

Dengan terbuktinya hipotesis pertama tersebut di atas maka dapat dikatakan bahwa tingkat efisiensi dari Bank Syariah Berbeda secara berarti dengan tingkat efisiensi dari Bank konvensional. Adapun tolok ukur dari tingkat efisiensi ini adalah ROE, yang mencerminkan imbal hasil bagi pemilik (pemegang saham). 
Kalau melihat pada data riil secara statistik bahwa ROE rata-rata (Mean) Bank Syariah selama periode 2003 dan 2004 adalah sebesar 11,71\%. Sementara itu ROE rata-rata Bank konvensional periode yang sama adalah sebesar $29,36 \%$, yang berarti lebih besar dibanding yang dicapai oleh Bank Syariah.

Namun demikian, apabila melihat pada deviasi standar sebagai pengukuran tingkat risiko, akan diperoleh kesimpulan yang lain. Deviasi standar dari ROE pada Bank Syariah adalah sebesar 10,42\%, yang lebih kecil bila dibanding dengan deviasi standar dari ROE pada Bank konvensional yang sebesar 14,24\%. Hal ini merefleksikan bahwa tingkat risiko usaha pada Bank Syariah adalah lebih rendah dibanding dengan Bank konvensional. Dengan kata lain dapat pula diberikan interpretasi bahwa ditinjau dari kepentingan pemilik (pemegang saham), Bank Syariah merupakan unit usaha yang lebih aman dalam hal menghadapi perubahanperubahan eksternal dibanding dengan unit usaha Bank konvensional. Dengan tingkat risiko (deviasi standar) yang lebih kecil, usaha Bank Syariah lebih menjamin bagi pemiliknya untuk mampu menjaga kontinuitasnya.

\section{Pembuktian Hipotesis Kedua}

Hipotesis kedua menyatakan bahwa terdapat pengaruh yang berarti dari komponen-komponen PM, AU dan EM terhadap ROE pada Bank Syariah dan Bank konvensional.

Untuk pembuktian hipotesis kedua ini, dipakai alat analisis Uji Koefisien Regresi Berganda untuk kelompok Bank Syariah dan untuk kelompok Bank konvensional. Adapun rumusnya adalah sebagai berikut:

$Y=B 0+B_{1} X_{1}+B_{2} X_{2}+B_{3} X_{3}$

Perumusan hipotesisnya yaitu:

Ho: $B_{1}=+B_{2}=B_{3}$

$\mathrm{H}_{1}$ : Sekurangnya satu estimator $\neq 0$

a. Tingkat Pengaruh PM, AU dan EM terhadap ROE pada Bank Syariah

Hasil analisis regresi yang diestimasikan untuk Bank Syariah adalah sebagai berikut:

$Y=14.904+1.075 X_{1}-0,746 X_{2}-0,417 X_{3}$

Nilai-nilai t-statistiknya sebagai berikut:

\begin{tabular}{|l|c|c|}
\hline \multicolumn{1}{|c|}{ Estimator } & T & Signifikansi \\
\hline Konstanta & 6,997 & 0,000 (sig.) \\
PM & 5,477 & 0,000 (sig.) \\
AU & $-3,766$ & 0,001 (sig.) \\
EM & $-3,475$ & 0,002 (sig.) \\
\hline
\end{tabular}

Nilai $F$ dan $R^{2}$ adalah sebagai berikut:

Nilai $F \quad=15,118$

Adjusted $\mathrm{R}^{2}=0,577$

Signifikansi $=0,000(\mathrm{sig})$ 
Dengan melihat pada hasil-hasil tersebut diatas dapat disimpulkan bahwa hipotesis kedua dapat dibuktikan, yaitu terdapat pengaruh yang berarti dari PM, AU dan EMT secara serempak terhadap ROE (Nilai $F=15,118$ yang signifikan). Adapun koefisien determinasinya (yaitu Adjusted $\mathrm{R}^{2}=0,577$ ) cukup moderat, walaupun diakui terdapat variabel-variabel lain (sebesar 0,423) yang tidak termasuk dalam model regresi ini.

Begitu pula koefisien-koefisien regresi dari estimator PM, AU dan EM memiliki nilai-nilai t-statistik yang seluruhnya signifikan. Hal ini dapat disimpulkan bahwa komponen-komponen PM, AU dan EM mempengaruhi ROE secara berarti.

\section{Pembahasan}

Berdasarkan uji koefisien regresi secara statistik tersebut diatas dapat diinterprestasikan bahwa peranan manajemen pemasaran bank (dengan proksi PM), cukup penting dalam menghasilkan tingkat efisiensi (dengan proksi ROE). Demikian pula kinerja dari manajemen aktiva (dengan proksi AU) memberikan kontribusi yang berarti terhadap pencapaian efisiensi bank. Disusul dengan cukup berperannya manajemen pasiva atau permodalan (dengan proksi EM) dalam mendongkrak tingkat efisiensi bank. Kondisi seperti ini patut dicatat oleh manajemen Bank Syariah bahwa, kebijakan-kebijakan manajerial di tiga bidang tersebut diatas perlu terus ditingkatkan karena telah terbukti memberikan kontribusi terhadap efisiensi usaha Bank Syariah.

Perlu dicatat bahwa Bank Syariah tidak menerapkan sistem bunga dalam operasionalnya, tetapi memakai sistem PLS (Profit and Loss sharing). Dalam melihat hasil-hasil analisis tersebut diatas dapat membuktikan bahwa sistem PLS telah mampu memperlihatkan kinerja manajerial yang cukup baik. Salah satu keunggulan dari Bank Syariah adalah terhindarnya dari risiko marjin yang negatif, sehingga Profit Margin (PM) menunjukkan koefisien yang terbaik (= $1,075)$ dalam menghasilkan tingkat efisiensi (ROE). Peringkat kedua adalah koefisien dari $\mathrm{AU}(=0,746)$ dan yang ketiga adalah koefisien dari $\mathrm{EM}(=0,417)$ yang berperan dalam penciptaan ROE.

b. Tingkat Pengaruh dari PM, AU dan EM terhadap ROE pada Bank konvensional.

Hasil estimasi persamaan regresi untuk Bank konvensional adalah sebagai berikut: $Y=1,341+0,440 X_{1}-0,144 X_{2}+0,047 X_{3}$

Nilai-nilai t statistiknya sebagai berikut:

\begin{tabular}{|l|c|c|}
\hline \multicolumn{1}{|c|}{ Estimator } & $\mathbf{t}$ & Signifikansi \\
\hline Konstanta & 1,536 & 0,136 (tak. sig.) \\
PM & 2,111 & 0,044 (sig.) \\
AU & $-0,686$ & 0,498 (tak. sig.) \\
EM & 0,258 & 0,798 (tak. sig.) \\
\hline
\end{tabular}


Nilai $\mathrm{F}$ dan $\mathrm{R}^{2}$ adalah sebagai berikut:

Nilai $F=1,560$

Adjusted $\mathrm{R}^{2}=0,051$

Signifikansi = 0,221 (Tak Sig.)

Berdasarkan hasil analisis tersebut diatas dapat disimpulkan bahwa hipotesis kedua tidak terbukti. Artinya PM, AU dan EM tidak mempengaruhi secara serempak terhadap ROE pada Bank konvensional (Nilai $F=1,560$ tidak signifikan). Demikian pula adjusted $R^{2}$ nya (hanya 0,051 ) sangat lemah pengaruhnya terhadap ROE.

Secara parsial hanya komponen PM yang pengaruhnya signifikan (sig = $0,044)$. Sementara AU $(t=0,498)$ tidak signifikan. Begitu pula EM $(r=0,798)$ tidak signifikan pengaruhnya terhadap ROE.

\section{Pembahasan}

Interpretasi yang dapat diberikan atas uji koefisien regresi pada bank konvensional tersebut diatas menggambarkan bahwa kebijakan-kebijakan yang diambil oleh manajemen bank konvensional tidak seluruhnya berhasil dalam membentuk efisiensi usaha. Nampak hanya dibidang manajemen pemasaran (dengan proksi PM) yang memberikan kontribusi yang signifikan terhadap ROE. Sementara dibidang manajemen aktiva (AU) dan manajemen pasiva (EM) peranannya lemah (tidak signifikan).

Lemahnya kinerja manajemen aktiva pada bank konvensional adalah diduga karena adanya kredit-kredit macet (Non Performing Loans) yang cukup besar sehingga menimbulkan aktiva yang tidak produktif. Demikian juga dibidang manajemen pasiva atau permodalan, bank konvensional ditengarai mengalami kelemahan terutama dalam menutup kerugian yang dihadapi dalam operasinya.

\section{KESIMPULAN DAN SARAN}

\section{Kesimpulan}

Berdasarkan hasil penelitian dan pembahasan maka dapat ditarik pokokpokok kesimpulan sebagai berikut:

a. Pembuktian Hipotesis Kesatu

Dari hasil analisis dapat dikemukakan temuan penelitian bahwa hipotesis kesatu dapat dibuktikan yaitu terdapat perbedaan yang berarti antara ROE pada Bank Syariah dengan ROE pada bank konvensional. Hal ini dapat dilihat pada nilai statistik dengan t-hitung (sebesar 5,580) pada tingkat signifikansi (sebesar $0,000)$. 
Makna dari temuan ini mencerminkan bahwa tingkat efisiensi (dengan proksi ROE) dari operasi Bank Syariah, berbeda secara berarti dibandingkan dengan tingkat efisiensi operasi bank konvensional.

Dari penelitian ini dapat pula dicatat bahwa ROE rata-rata dari Bank Syariah (sebesar 11,71\%) lebih rendah dibanding dengan ROE rata-rata bank konvensional (sebesar 29,36\%). Namun ditinjau dari deviasi-standar dari ROE, Bank Syariah (sebesar 10,42\%) lebih kecil dibanding dengan bank konvensional (sebesar 14,34\%). Hal ini memberi makna bahwa tingkat risiko dari operasi Bank Syariah lebih rendah dibanding dengan bank konvensional.

b. Pembuktian Hipotesis Kedua

(1) Pada Bank Syariah dapat dikemukakan temuan penelitian bahwa komponen-komponen Profit Margin (PM); Asset Utilization (AU) dan Equity Multiplier (EM) secara serempak memiliki pengaruh yang berarti terhadap ROE. Hal ini dapat dilihat pada F Statistik (sebesar 15,118) dengan tingkat signifikansi (sebesar 0,000).

Temuan ini memberi makna bahwa kebijakan-kebijakan pada bidang manajemen pemasaran (dengan proksi PM), bidang manajemen aktiva (dengan proksi $\mathrm{AU}$ ) dan bidang manajemen pasiva (dengan proksi EM) memberikan peranan yang berarti dalam pencapaian tingkat efisiensi (dengan proksi ROE) pada Bank Syariah.

Adapun kontribusi terbesar dalam pencapaian ROE adalah dari PM ( $\mathrm{t}=$ $5,477)$, lalu disusul dari $A U(t=3,766)$ dan dari EM $(t=3,475)$.

(2) Pada Bank konvensional dapat diungkapkan temuan penelitian bahwa komponen-komponen PM, AU dan EM secara serempak tidak memiliki pengaruh yang berarti terhadap ROE. Hal ini dapat dilihat pada nilai $F$ Statistik (sebesar 1,560) dengan signifikansi (sebesar 0,221).

Temuan ini merefleksikan bahwa kebijakan-kebijakan yang ditempuh oleh bank konvensional dibidang manajemen pemasaran, manajemen aktiva dan manajemen pasiva tidak memberikan peranan yang berarti terhadap tingkat efisiensi yang dicapai.

Sementara itu, komponen yang memberikan kontribusi yang berarti hanya dari PM (signifikansi sebesr 0,044). Sedangkan dari komponen-komponen AU dan EM tidak memberikan kontribusi yang berarti.

\section{Saran-saran}

Dengan menyadari adanya keterbatasan-keterbatasan dalam penelitian ini terutama yang menyangkut data penelitian dan metode analisisnya maka dalam upaya untuk mencapai hasil-hasil yang lebih baik dapat disarankan hal-hal sebagai berikut:

a. Untuk penelitian selanjutnya tentang studi komparasi antara Bank Syariah dan Bank konvensional, kiranya dapat dikumpulkan data penelitian yang lebih 
banyak (dengan jumlah sampel yang lebih besar) sehingga dapat dicapai generalisasi hasil penelitian yang lebih baik.

b. Dibidang alat analisis, kiranya dapat dicoba untuk menggunakan metode yang lain seperti analisis diskriminan, sehingga studi komparasi antara kinerja Bank Syariah dan Bank konvensional dapat dilakukan secara lebih tajam mengenai faktor-faktor dominannya.

c. Hal lain yang perlu diperhatikan dalam suatu penelitian yang bersifat luas cakupannya yaitu tentang periode penelitian yang semestinya lebih panjang, misalnya minimal selama lima tahun.

\section{DAFTAR PUSTAKA}

Adnan. M. Akhyar, (1996). An Investigation of Accounting Concept and Practices in Islamic Bank. The Cases of Bank Islam Malaysia Berhad and Bank Muamalat Indonesia. Ph.D. Thesis, Universsity of Wallongang.

Ahmad. Ausaf. (1987). Development and Problems of Islamic Banks, Jeddah: Islamic Development Bank, Islamic Research and Training Institute.

Akkas, Ali. (1996). Relative Efficiencies of the Conventional and Islamic Banking System in Financing Investment. Unpublished Ph, D. Dissertation, Dhaka University.

Bashir, Abdel-Hameed, (2000). Determinants of Profitability and Rate of Retrun Margins is Islamic Banks. Some Evidence From The Middle East", Department of Economics Grambling State University, Grambling, LA.

Cole, David, (1973). Return On Equity Model for Banks. The Bankers Magazine, Spring.

Errico, Luca and Farahbaksh, Mitra, (1998). Issues in Prudential Regulations and Supervision of Islamic Banking. Proceedings of the Second Harvard University Forum on Islamic Finance. Harvard University, Cambridge, Massachusetts, October 9-10.

Gamal, Mohmoud A., (1998). The Survival of Islamic Banking: A Micro-evalutionary Perpective. Proceeding of the Second Harvard University Forum on Islamic Finance, Harvard University, Cambridge, Massachusetts, October 9-10.

Gujarati, D., (1997). Ekonometrika Dasar. Penerbit Erlangga. Jakarta.

Hempel, George H., (1994). Bank Management: Text and Cases, Fourth Edition, John Wiley \& Sons Inc., NY.

, (1997). Financial Management of Financial Institutions. Englewood Cliffs, NJ. Prentice Hall. 
Hussein, Khaled A., (2001). Operational Efficiency in Islamic Banking: The Sudanese Experience. Islamic Research and Training Institute, Islamic Development Bank, Jeddah, Saudi Arabia.

Iqbal, Munawar., (2000). Islamic and Coventional Banking in Nineties: A Comporatiove Study, Longhborough University, UK, August' 13-15.

Kader, Radiah Abdul, (1995). Bank Islam Malaysia Marketing Implications, Leading Issues in Islamic Banking and Finance. Pelanduk Publications Sdn, Berhad, Malaysia, 103-129.

Lewis, M.K. \& Latifa, Algarud, (2001). Islamic Banking. Edward Elgor Publishing Inc. Massachusetts, USA.

Liman, Imed, (2000). Measuring Technical Efficiency of Kuwait Banks. Department of Economics Grambling State University, Grambling. I.A.

Rose, Peter S., (1995). Commercial Bank Management. Illinois, Irwin.

Rose, Peter S., and Kolari, James W., (1995). Financial Institutions. Fifth Edition, Irwin, Chichago.

Samad, Abdus, (1999). Comparative Efficiency of The Islamic Bank vis-à-vis Conventional Banks in Malaysia, IIUM Journal of Economics and Management, Volume 7, Number 1.

Sinungan, Muchdarsyah, (1987). Uang dan Bank, Bina Aksara, Cetakan I, Jakarta.

Wong, Choo Sum, (1995). Bank Islam Malaysia, Performance Evaluation 1983-1993. Leading Issues in Islamic Banking and Finance. Pelanduk Publication Sdn. Bhd., Malaysia, 83-102. 